\title{
TOXIC ELEMENTS AS A RISK FACTOR FOR THE SURVIVAL OF THE HONEY BEES (Apis mellifera L.)
}

\author{
Milica Živkov Baloš ${ }^{*}$, Željko Mihaljev ${ }^{1}$, Sandra Jakšić ${ }^{1}$
}

${ }^{1}$ Scientific Veterinary Institute „Novi Sad“, Novi Sad, Republic of Serbia

\begin{abstract}
Toxic element pollution is an ecological concern in the regions where mining, industry and agriculture are developing. Anthropogenic impact on the environment results in the reduction of the population of honey bees worldwide with varying degrees of morbidity and mortality. Bees exposed to contaminants produce polluted products through various sources, including foraging activities on contaminated plants. Therefore, monitoring of honey bee products in terms of toxic elements is very important for food safety and for preventing potential future ecological problems. The data presented in this review are useful for bee health protection and improving the quality and safety of honey production chain.
\end{abstract}

Key words: honey bee, honey, toxic elements

${ }^{1 *}$ Corresponding Author: milica@niv.ns.ac.rs 


\title{
TOKSIČNI ELEMENTI - FAKTOR RIZIKA ZA PREŽIVLJAVANJE MEDONOSNIH PČELA (Apis mellifera L.)
}

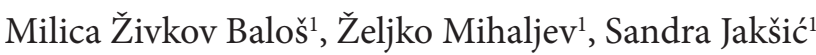

${ }^{1}$ Naučni institut za veterinarstvo „Novi Sad“, Novi Sad, Republika Srbija

\section{Kratak sadržaj}

Kontaminacija životne sredine toksičnim elementima je ekološki problem u regijama sa razvijenim rudarstvom, industrijom i poljoprivredom. Antropogeni uticaj na životnu sredinu utiče na smanjenje populacije medonosnih pčela u svetu, sa različitim stepenom morbiditeta i mortaliteta. Pčele izložene toksičnim elementima, iz različitih izvora, uključujući aktivnosti prikupljanja nektara i polena sa kontaminarinih biljaka, proizvode kontaminirane proizvode. Stoga je monitoring toksičnih elemenata $\mathrm{u}$ pčelinjim proizvodima važan za bezbednost pčelinjih proizvoda kao hrane, a takođe i za sprečavanje budućih ekoloških problema. Informacije u ovom radu mogu biti korisne za unapređenje i zaštitu zdravlja pčela i poboljšanje kvaliteta i bezbednosti meda.

Ključne reči: pčela, med, toksični elementi

\section{INTRODUCTION}

Honey bee (Apis mellifera L.) is an extremely important insect not only for humans, but also for the entire ecosystem to function. Honey bee is completely dependent on flowering plants (Roman et al., 2011). They forage over very large areas and bring plant materials (nectar, pollen, propolis and honeydew) to their hives. Toxicological conditions of the environment in which honey bees live directly affect them, since their existence is directly related to the natural environment. For these reasons, honey bees and their products are considered as good bioindicators of environmental pollution (Aljedani, 2020; Costa et al., 2019; Chicas-Mosier et al., 2017).

Environmental and food contamination with toxic elements has pronounced carcinogenic and mutagenic effects, causing poisoning and metabolism disruption (Murashova et al., 2020). Although trace elements (micronutrients) play an important role in the metabolism, they have potentially harmful effects. The micronutrient metals (zinc, $\mathrm{Cu}$, iron, selenium, chromium, etc.) 
can contribute to neurodegeneration, if they are outside their biologic range (Chicas-Mosier et al., 2017). In addition, combined effects of co-exposure to different metals can also occur (Monchanin et al., 2021). The non-essential elements (lead, cadmium, mercury) can be toxic even in a trace amount. Regarding their level of hazard, chemical elements are divided into three groups:

1. highly hazardous substances (arsenic (As), cadmium (Cd), mercury (Hg), lead $(\mathrm{Pb})$, zinc $(\mathrm{Zn}))$;

2. moderately hazardous substances (copper $(\mathrm{Cu})$, molybdenum (Mo), chromium $(\mathrm{Cr})$, tin $(\mathrm{Sn}))$;

3. low hazard substances (tungsten (W), barium (Ba), strontium (Sr), manganese (Mn)) (Murashova et al., 2020).

This review is aimed at reporting the information about the impact of some toxic and potentially toxic elements on honey bee health and survival. Since honey bee products are widely used in human nutrition, and may be contaminated with toxic elements, the present review addresses the first of all apicultural and food scientists. This information should be passed on to beekeepers so that they can protect bee communities from the effects of environmental contamination and produce safe bee products.

\section{TOXIC ELEMENTS - EXPOSURE AND TOXICITY FOR HONEY BEE}

$\mathrm{Pb}$ is one of most widespread environmental contaminants, and its content is a subject of numerous environmental studies (Bilandžić et al., 2011). This toxic element is a natural component of the biogeosphere, and it enters the environment from metal smelters, coal-fired power plants, from sewage sludge or waste oil, or as a result of solid waste combustion. The amount of $\mathrm{Pb}$ from natural sources in the biosphere is small compared to anthropogenic $\mathrm{Pb}$ sources. However, the dominant anthropogenic emission of $\mathrm{Pb}$ into the environment was the result of the use of organo- $\mathrm{Pb}$ compounds - additives in the oil industry. $\mathrm{Pb}$ use in automobile fuels was forbidden a few years ago, but air and water contamination is still quite high (Lambert et al., 2012). The primary sources of $\mathrm{Pb}$ exposure for animals are contaminated soil, $\mathrm{Pb}$ paint on decrepit buildings, $\mathrm{Pb}$ contaminated water, and $\mathrm{Pb}$ based products like batteries (Waldner et al., 2002). The bioavailability of $\mathrm{Pb}$ in soil to plants depends on soil acidity and the content of organic matter. Higher soil acidity and lower organic matter content will cause higher $\mathrm{Pb}$ bioavailability. Translocation of $\mathrm{Pb}$ ions in plants is limited. The largest amounts of $\mathrm{Pb}$ are found in cell walls of root cells. 
$\mathrm{Pb}$ is accumulated mainly inside the organs of bees feeding in industrial areas. Low levels of $\mathrm{Pb}$ exposure cause unspecified cardiovascular, haematological, and neurodevelopmental changes (NRC, 2005). In natural feeding areas, most of $\mathrm{Pb}$ is found on the surface of bee bodies (Sadowska et al., 2019). Pb negatively affects bees' immune system - it slows down appetitive learning and reduces long-term memory specificity (Monchanin et al., 2021).

Most industrially produced As originates from agricultural products such as insecticides, herbicides, fungicides, algicides, wood preservatives, and growth stimulators for plants and animals (Eisler, 1988). The use of pesticides containing As as well as other chemical products in agriculture results in As accumulation in soil and plants and consequent finding of As as a trace element in the environment and food (Roy and Saha, 2002; Mandal, 2017). As causes poisoning that is associated with stomach pain. It is a protoplasmic poison. When consumed by insects, arsenicals are absorbed through the midgut or ventriculus wall. The toxicity of As is attributed to tissue and epithelium disintegration and protein precipitation. Poisoned honey bees display the symptoms such as inability to fly, distended abdomens, and diarrhoea. Honey bees often die of poisoning during foraging. The As source for nonforaging adult bees is contaminated pollen, nectar, and water brought by foragers. The majority of bees that die in the hive are nurse bees (Fujii, 1980).

The concentration of $\mathrm{Cd}$ in the environment increases significantly due to natural sources (volcanic activity, weathering and erosion) and anthropogenic activities (mining, smelting, industrial production of plastics, dry batteries, paints, and also through phosphate fertilizers that contain significant amounts of Cd) (Polykretis et al., 2016; Satarug et al., 2003). Cd is actively absorbed by plant roots, it is transferred into nectar and pollen, and it subsequently accumulates in pollinators and their products (Bogdanov, 2006). Polykretis et al. (2016) showed in their study that Cd causes a reduction in immunocompetence in 3 days following the exposure to $\mathrm{Cd}$ in honey bees.

The impact of the elements like $\mathrm{Hg}$, aluminium ( $\mathrm{Al}), \mathrm{Cr}$, nickel $(\mathrm{Ni})$ and other potentially toxic elements on bees has been studied much less. $\mathrm{Al}$ is present in the soil in variable concentrations. Bioavailability of $\mathrm{Al}$ to organisms is increasing through mining activity, soil acidification, and carbon emission. In acidic environments, it can be a major limiting factor to many plants and aquatic organisms. Al exposure may be detrimental to foraging bee behaviours and to other ecologically relevant behaviours. Chicas-Moiser et al. (2017) showed that $\mathrm{Al}$ affects floral decision making of bees potentially by altering sucrose perception, increasing the activity level and reducing the likelihood of foraging on uncontaminated resources. Selenium (Se) is a micronutrient 
and an essential mineral to plants and animals. This element is naturally found in alkaline lands, but agricultural water dissolves it, leading to a build-up of selenates, the bioavailable form of Se. Hladun et al. (2012) concluded that the bees fed selenate were less responsive to sucrose. It is possible that this will lead to a reduction in incoming food resources in the hive. Besides, if honey bees forage on nectar containing Se, reduction in population numbers may occur, due to direct toxicity. The same authors stated that it is possible that honey bees cannot detect detrimental concentrations of Se.

During foraging activities bees are exposed to pollutants. Their hairy bodies can keep different particles from the atmosphere, soil and water, and therefore, the toxic element levels in honey may reflect the actual amount in the environment (Costa et al., 2019; Islam et al., 2014; Lambert et al., 2012; Porrini et al., 2003; Przybyłowski and Wilczyńska, 2001). In some cases, ultra-fine particles of metal are inhaled by honey bees when they fly (Borg and Attard, 2020). However, bees can be exposed to contaminants through ingestion of contaminated pollen and nectar (Di et al., 2016).

Honey bees may be exposed to metal pollution found in an area of around $7 \mathrm{~km}^{2}$ surrounding the hives (Đogo Mračević et al., 2020). Contamination of honey bees and their products by toxic elements may be a result of the industrial development, urbanization and transport (Hamad et al., 2020; Tutun et al., 2019; Lambert et al., 2012; Bilandžić et al., 2011). In addition to the above-mentioned sources, contamination of honey may be caused by the use of wrong procedures during harvesting, fumigation, extraction and processing, storage and conservation phases (Bartha et al., 2020).

Toxic elements from the soil accumulate in plants and migrate to the body of bees and reach the consumers through honey products and food chain. It is known that plants accumulate toxic elements not only from the soil but from the air as well. The type of plant, the mobility and bioavailability of toxic elements affect transfer from soil to flowers or other parts of the plants visited by foraging bees. Herbaceous plants of natural biocenoses have a greater potential to accumulate toxic elements compared to agrocenoses (Murashova et al., 2020). It is important to point out that the literature clearly shows that sunflower can accumulate toxic elements ( $\mathrm{As}, \mathrm{Pb}, \mathrm{Cu}, \mathrm{Cd}, \mathrm{Ni}, \mathrm{Cr}, \mathrm{Co}$ ), mainly in shoots and roots (Dhiman et al., 2017; Stoikou et al., 2017; Angelova et al., 2016; Garcia et al., 2006). Since growing sunflower plants has a high potential to collect metal contaminants, they are considered "hyperaccumulators" of metals (Dhiman et al., 2017).

In addition to affecting plant health, survival and productivity, environmental contamination exposes pollinators that depend on these plants to po- 
tentially toxic levels of toxic elements. The sublethal accumulation of some metals and metalloids in the pollen and nectar of flowering plants can have a significant effect on pollinator health and survival (Burden et al., 2019). Some studies confirm that bees have the ability to detect some contaminants through receptors on antennae and proboscis (Burden et al., 2019; de Brito Sanchez, 2011). Foraging bees do not detect some toxic elements, like Cd and Se, they may readily consume them and therefore have a major effect on the health and survival of the colony (Hladun et al., 2012; Burden et al., 2019). Still, honey bees can reject contaminated food, the toxic levels of metals and metalloids in the environment are still a significant risk to pollinators.

During foraging activities, worker bees partially purify raw material for honey production from contaminants. That is why there is a lower level of toxic elements in products than in raw material for honey production (Roman et al., 2011). According to the research conducted in different countries, the concentrations of toxic elements in honey and honey bee products decreases in following order: bee $>$ pollen $>$ wax $>$ propolis and nectar $>$ honey (Roman et al., 2011; Lambert et al., 2012; Formicki et al., 2013; Aljedani, 2020; Gutiérrez et al., 2020). The metals accumulate over time in the bees' organs and the nest, leading to toxic effects on the larvae and older bees (Aljedani, 2020; Burden et al., 2019; Sadowska et al., 2019). Contaminants also accumulate in the hive. Di et al., 2016, Formicki et al. (2013) showed in their study that Cd accumulates the most in beeswax, while $\mathrm{Pb}$ content was high in both wax and honey. Exposure of honey bees to $\mathrm{As}, \mathrm{Cu}$ or $\mathrm{Pb}$ reduces learning and memory performances (Monchanin et al., 2021). Larvae are much more sensitive to the sublethal and lethal concentrations of metals than adult bees, and they exhibit significantly increased mortality (Burden et al., 2019).

\section{TOXIC ELEMENTS IN HONEY BEE PRODUCTS}

Honey bee products are regarded as natural, healthy and clean (Bogdanov, 2006), but the public is generally not informed about the fact that honey may also contain substances that could be toxic. Honey is a natural food with nutritional, sensory and potentially therapeutic properties consumed without any processing and is characterized by complex composition (Sergalio et al., 2019). Honey has been recognized as a source of energy in human nutrition (Boussaid et al., 2018) because its sugars are easily digestible (El Sohaimy et al., 2015) and it is widely used as a sweetener in food industry and in a large number of food products (Amiry et al., 2017; Kek et al., 2017). These properties are related to the chemical composition of honey. The possible health benefits of consuming honey and bee products have been documented in early Greek, 
Roman, Vedic, and Islamic texts and the healing qualities of honey were addressed by philosophers and scientists all the way back to ancient times (Prica et al., 2015).

The major component of honey is sugar, although other minor components, such as enzymes, proteins, organic acids, vitamins, minerals, pollen grains, waxes and phytochemicals, are also present (Buba et al., 2013; Sousa et al., 2016; Kek et al., 2017; Živkov Baloš et al., 2019).

The properties and composition of honey depend on the region, bee species, production season, floral source, soil characteristics, the period when it is stored in the honeycomb, method of harvesting and postharvest storage (Živkov Baloš et al., 2020). Mineral concentrations in honey depend on botanical origin, climate conditions, and significantly on geographical origin and type of soil in which the plants grow (Živkov Baloš et al., 2018; Lazarević et al., 2017; Uršulin-Trstenjak et al., 2015; Formicki et al., 2013). The minerals mainly originate from the soil and nectar-producing plants, but they may also come from anthropogenic sources, such as environmental pollution (Solayman et al., 2016). Solayman et al. (2016) listed 54 minerals reported to be found in honey in the literature on honey published in the past 15 years, from all over the world. The mineral content of honey contributes to the colour of the honey. Darker honey types are richer in minerals. Black locust and sunflower honey are characterised by low concentrations of ash and minerals, compared to meadow, chestnut and honeydew honey (Lasić et al., 2018; Dhahir and Hemed, 2015; Uršulin-Trstenjak et al., 2015). Electrical conductivity (EC) is closely related to the concentration of minerals. Lighter honey types are characterized by a lower EC than the darker ones (Živkov Baloš et al., 2018; Živkov Baloš et al., 2019a).

Honey and other bee products can be a useful indicator for assessing environmental pollution (Živkov Baloš et al., 2021; Đogo Mračević et al., 2020; Sergalio et al., 2019; Lazarević et al., 2017; Moniruzzaman et al., 2014; Bilandžić et al., 2011). Traffic-related pollution and chemical intensive agriculture contaminate the air, water, and soil, which also leads to the increasing levels of some toxic elements in honey bee products. The increased levels of some toxic elements were found in close proximity to industrial areas (Bartha et al., 2020; Hamad et al., 2020; Sadowska et al., 2019; Formicki et al., 2013; Bilandžić et al, 2011). $\mathrm{Pb}$ is metal whose maximum content in honey is limited by regulations. The maximum permissible value of $\mathrm{Pb}$ is prescribed by national regulation on maximum concentrations of certain contaminants in food and it is set at 0.10 $\mathrm{mg}$ of $\mathrm{Pb} / \mathrm{kg}$ for honey (Official Gazette, 81/2019). This regulation is harmonized with the European regulation (Commission Regulation, 1005/2015). 
In our previous study, $\mathrm{Pb}$ concentrations ranged from 0.002 to $0.096 \mathrm{mg} /$ $\mathrm{mg}$ with a mean value of $0.051 \mathrm{mg} / \mathrm{kg}$ in fifteen sunflower honey samples from all the examined locations in Serbia (Živkov Baloš et al., 2021). The following $\mathrm{Pb}$ levels have been found in the honey from different countries: Croatia (65.2 $\mu \mathrm{g} / \mathrm{kg}$; reported by Bilandžić et al., (2011) and $0.02-0.11 \mathrm{mg} / \mathrm{kg}$; reported by Uršulin-Trstenjak et al., (2015)), Romania (51.674 $\mu \mathrm{g} / \mathrm{kg}$; Oroian et al., 2016), Poland $(0.048 \mathrm{mg} / \mathrm{kg}$; Przybyłowski and Wilczyńska, 2001), Turkey (0.80 $\mathrm{mg} / \mathrm{kg}$; Tutun et al., 2019), Iran (507.58 $\mu \mathrm{g} / \mathrm{kg}$; Aghamirlou et al., 2015), Iraq $(0.108-0.820 \mathrm{mg} / \mathrm{kg}$; Dhahir and Hemed, 2015), and Malaysia $(0.36 \mathrm{mg} / \mathrm{kg}$; Moniruzzaman et al., 2014). The authors of the cited articles have concluded that higher concentrations of $\mathrm{Pb}$ in the examined honey samples may be a result of the location of hives in the areas, as they were near roads, industrial or building sites.

\section{CONCLUSION}

The danger of honey bee extinction is a significant issue not only from the aspect of ecology, but also from the economic point of view. The accumulation of toxic metals in the pollen and nectar of flowering plants can have a detrimental effect on honey bee health and survival. Honey and honey bees are good indicators used for monitoring of environmental pollution. Mineral composition of honey bee products is strongly affected by both natural and anthropogenic factors. The data presented in this paper are useful for improving the quality of honey production chain. Beekeepers should pick the location of their hives with caution. The procedures applied during the production and processing of honey should be in accordance with hygiene standards, in order to prevent the contamination of bee products from beekeeping source. Besides, it is important to monitor the levels of toxic elements in the honey and honey bees in terms of their toxicity and for the prevention of future ecological issues.

\section{ACKNOWLEDGEMENT}

This study was funded by Ministry of Education, Science and Technological Development of Republic of Serbia by the Contract of implementation and funding of research work of NIV-NS in 2021, Contract No: 451-03-9/202114/200031 and was also supported by Provincial Secretariat for Agriculture, Water Management and Forestry of Vojvodina, Contract No: 104-401$4672 / 2021 / 01$. 


\section{Author's Contribution:}

M.Ž.B. drafted the manuscript and made substantial contributions to the basic idea; Ž.M. were involved in drafting of the manuscript; S.J. revised the manuscript critically.

\section{Competing interest}

The authors declare that they have no competing interests.

\section{REFERENCES}

1. Aghamirlou H.M., Khadem M., Rahmani A., Sadeghian M., Mahvi A.H., Akbarzadeh A., Nazmara S. 2015. Heavy metals determination in honey samples using inductively coupled plasma-optical emission spectrometry. Journal of Environmental Health, 13, 39. doi:10.1186/s40201-015-0189-8.

2. Amiry S., Esmaiili M., Alizadeh M. 2017. Classification of adulterated honeys by multivariate analysis. Food Chemistry, 224, 390-397. doi: 10.1016/j.foodchem.2016.12.025.

3. Aljedani D.M. 2020. Revealing some elements and heavy metals in honeybee and beeswax samples collected from different environments. Entomology and Applied Science Letters, 7, 4, 89-101.

4. Angelova V.R., Perifanova-Nemska N., Uzunova G.P., Ivanov K.I., Lee H.Q. 2016. Potential of sunflower (Helianthus annuus L.) for phytoremediation of soils contaminated with heavy metals. World Academy of Science, Engineering and Technology International Journal of Environmental and Ecological Engineering, 10, 9, 576-583. doi: 10.5281/zenodo.1126371.

5. Bartha S., Taut I., Goji G., Vlad I.A., Dinulică F. 2020. Heavy metal content in polyfloral honey and potential health risk. A case study of Copşa Mică, Romania. International Journal of Environmental Research and Public Health, 17, 1507. doi: 10.3390/ijerph17051507.

6. Bilandžić N., Đokić M., Sedak M., Solomun Kolanović B., Varenina I., Končurat A., Rudan N. 2011. Determination of trace elements in Croatian floral honey originating from different regions. Food Chemistry, 128, 1160-1164. doi: 10.1016/j.foodchem.2011.04.023.

7. Bogdanov S. 2006. Contaminants of bee products. Apidologie, 37, 1-8. doi: 10.1051/apido:2005043.

8. Borg D., Attard E. 2020. Honeybees and their products as bioindicators for heavy metal pollution in Malta. Acta Brasiliensis, 4, 1, 60-69. doi: $10.22571 / 2526-4338282$. 
9. Boussaid A., Chouaibi M., Rezig L., Hellal R., Donsi F., Ferrari G., Hamdi S. 2018. Physicochemical and bioactive properties of six honey samples from various floral origins from Tunisia. Arabian Journal of Chemistry, 11, 265-274. doi:10.1016/j.arabjc.2014.08.011.

10. Buba F., Gidado A., Shugaba A. 2013. Analysis of Biochemical Composition of Honey Samples from North-East Nigeria. Biochem. Anal Biochem. 2, 3, 2-7, doi: 10.4172/2161-1009.1000139.

11. Burden C.M., Morgan M.O., Hladun K.R., Amdam G.V., Trumble J.J., Smith B.H. 2019. Acute sublethal exposure to toxic heavy metals alters honey bee (Apis mellifera) feeding behavior. Scientific Reports, 9, 4523. doi: 10.1038/s41598-019-40396-x.

12. Chicas-Mosier A.M., Cooper B.A., Melendez A.M., Pérez M., Oskay D., Charles I. Abramson C.I., 2017. The effects of ingested aqueous aluminum on floral fidelity and foraging strategy in honey bees (Apis mellifera). Ecotoxicology and Environmental Safety, 143, 80-86. doi: 10.1016/j.ecoenv.2017.05.008.

13. Commission Regulation (EU). 2015. No 2015/1005 of 25 June 2015 amending Regulation (EC) No. 1881/2006 as regards maximum levels of lead in certain food stuffs. OJ I. 161, 9-13.

14. Costa A., Veca M., Barberis M., Tosti A., Notaro G., Nava S., Lazzari M., Agazzi A., Tangorra F.M. 2019. Heavy metals on honeybees indicate their concentration in the atmosphere. A proof of concept. Italian Journal of Animal Science, 18, 1, 309-315. doi: 10.1080/1828051X.2018.1520052.

15. De Brito Sanchez, M.G. 2011. Taste perception in honey bees. Chemical Senses, 36, 675-692, doi: 10.1093/chemse/bjr040.

16. Di N., Hladun K.R., Zhang K., Liu T.X., Trumble J.T. 2016. Laboratory bioassays on the impact of cadmium, copper and lead on the development and survival of honeybee (Apis mellifera L.) larvae and foragers. Chemosphere, 152, 530-538. doi: 10.1016/j.chemosphere.2016.03.033.

17. Dhahir S.A., Hemed A.H. 2015. Determination of heavy metals and trace element levels in honey samples from different region of Iraq and compared with other kind. American Journal of Applied Chemistry, 3 (3), 83-92. doi: 10.11648/j.ajac.20150303.11.

18. Dhiman S.S., Zhao X., Li J., Kim D., Kalia V. C., Kim I-W., Kim J.Y., Lee J-K. 2017. Metal accumulation by sunflower (Helianthus annuus L.) and the efficacy of its biomass in enzymatic saccharification. PLoS ONE, 12(4), 1-14. doi: 10.1371/journal.pone.0175845.

19. Đogo Mračević S., Krstić M., Lolić A., Ražić S. 2020. Comparative study of the chemical composition and biological potential of honey from different regions of Serbia. Microchemical Journal, 152, 104420. doi: 10.1016/j. microc.2019.104420. 
20. Eisler R. 1988. Arsenic hazards to fish, wildlife, and invertebrates: a synoptic review. Contaminant Hazard Reviews U.S. Fish and Wildlife Service, Biological Report 85 (1.12).

21. El Sohaimy S.A., Masry S.H.D., Shehata M.G. (2015). Physicochemical characteristics of honey from different origins. Annals of Agricultural Sciences, 60(2), 279-287. doi:10.1016/j.aoas.2015.10.015.

22. Formicki G., Greń A., Stawarz R., Zyśk B., Gal A. 2013. Metal content in honey, propolis, wax, and bee pollen and implications for metal pollution monitoring. Polish Journal of Environmental Studies, 22, 1, 99-106.

23. Fujii L. 1980. Oral dose toxicity vs. tissue residue levels of arsenic in the honey bee (Apis mellifera L.). Graduate student Theses, Dissertations \& Professional Papers, University of Montana, Scholar Works at University of Montana, 7211. https://scholarworks.umt.edu/etd/7211

24. Garcia J.S., Gratão P.L., Azevedo R.A., Arruda M.A.Z. 2006. Metal contamination effects on sunflower (Helianthus annuus L.) growth and protein expression in leaves during development. Journal of Agricultural and Food Chemistry, 54, 8623-8630.

25. Gutiérrez M., Molero R., Gaju M., van der Steen J., Porrini C., Ruiz J.A. 2020. Assessing heavy metal pollution by biomonitoring honeybee nectar in Córdoba (Spain). Environmental Science and Pollution Research, 27, 10436-10448. doi: 10.1007/s11356-019-07485-w.

26. Hamad G.M., Hafez E.E., Abdelmotilab N.M., Abdel-Hmeed K.M., Ali S.H. 2020. Quality assesment, functional potentials, and safety evaluation of stored Egyptian honey as an environmental pollution bioindicator. Environmental Toxicology and Chemistry, 39, 10, 1894-1907. doi: 10.1102/etc.4811.

27. Hladun K.R., Smith B.H., Mustard J.A., Morton R.R., Trumble J.T. 2012. Selenium toxicity to honey bee (Apis mellifera L.) pollinators: Effects on behaviors and survival. PloS ONE, 7, 4, e34137. doi:10.1371/jornal. pone.0034137.

28. Islam M.N., Khalil M.I., Islam M.A., Gan S.H. 2014. Toxic compounds in honey. Journal of Applied Toxicology, 34, 733-742. doi: 10.1002/jat.2952.

29. Kek S. P., Chin N. L., Yusof Y. A., Tan S. W., Chua L. S. 2017. Classification of entomological origin of honey based on its physicochemical and antioxidant properties. International Journal of Food properties, 20, 3, 2723 2738. doi: 10.1080/10942912.2017.1359185.

30. Lambert O., Piroux M., Puyo S., Thorin C., Larhantec M., Delbac F., Pouliquen H. 2012. Bees, honey and pollen as sentinels for lead environmental contamination. Environmental Pollution, 170, 254-259. doi: 10.1016/j. envpol.2012.07.012. 
31. Lasić D., Bubalo D., Bošnir J., Šabarić J., Konjačić M., Dražić M., Racz A. 2018. Influence of the Botanical and geographical origin on the mineral composition of honey. Agriculture Conspectus Scientificus, 83, 4, 335-343. doi: 10.5740/jaoacint.17-0143.

32. Lazarević K.B., Jovetić M.S., Tešić Ž.Lj. 2017. Physicochemical parameters as a tool for the assessment of origin of honey. Journal of AOAC International, 100, 4, 840-851. doi: 10.5740/jaoacint.17-0143.

33. Mandal P. 2017. An insight of environmental contamination of arsenic on animal health. Emerging Contaminants, 3, 1, 17-22. doi: 10.1016/j. emcon.2017.01.004.

34. Monchanin C., Drujont E., Devaud J.M., Lihoreau M., Barron A.B. 2021. Metal pollutants have additive negative effects on honey bee cognition. Journal of experimental Biology, 224, 12. doi: 10.1242/jeb.241869.

35. Moniruzzaman M., Chowdhury M.A.Z., Rahman M.A., Sulaiman S.A., Gan S.H. 2014. Determination of Mineral, Trace Element, and Pesticide Levels in Honey Samples Originating from Different Regions of Malaysia Compared to Manuka Honey. BioMed Research International, 10, doi: 10.1155/2014/359890.

36. Murashova E.A., Tunikov G.M., Nefedova S.A., Karelina O.A., Byshova N.G., Serebryakova O.V. 2020. Major factors determining accumulation of toxic elements by bees and honey products. International Transaction Journal of Engineering, Management, \& Applied Sciences \& Technologies, 11, 3, 11A03N: 1-14. doi: 10.14456/ITJEMAST.2020.54.

37. National Research Council (NRC). 2005. Mineral tolerance of animals. Second revised edition, Committee on minerals and toxic substances in diets and water for animals, Board on agriculture and natural resources, Division on earth and life studies. National Academy Press, Washington D.C., USA, ISBN 0-309-09654-5.

38. Official Gazette Republic of Serbia. 2019. Rulebook on maximum concentrations of certain contaminants in food, No. 81.

39. Oroian M., Prisacaru A., Hretcanu E.C., Stroe S.G., Leahu A., Buculei A. 2016. Heavy metals profile in honey as a potential indicator of botanical and geographical origin. International Journal of Food Properties, 19, 1825-1836. doi: 10.1080/109442912.2015.1107578.

40. Porrini C., Sabatini A.G., Girotti S., Ghini S., Medrzycki P., Grillenzoni F., Bortolotti L., Gattavecchia E., Celli G. 2003. Honey bees and bee products as monitors of the environmental contamination. Apiacta, 38, 63-70.

41. Polykretis P., Delfino G., Petrocelli I., Cervo R., Tanteri G., Montori G., Perito B., Branca J.J.V., Morucci G., Gulisano M. 2016. Evidence of immu- 
nocompetence reduction induced by cadmium exposure in honey bees (Apis mellifera). Environmental Pollution, 218, 826-834. doi: 10.1016/j. envpol.2016.08.006.

42. Prica N., Živkov Baloš M., Jakšić S., Mihaljev Ž., Ljubojević D., Vidić B., Savić S. 2015. Physicochemical analysis as an indicator of the quality of honey originating from Vojvodina region. In Book of Proceedings, First International Symposium of Veterinary Medicine (ISVM2015) „One Health - New Challenges", Hotel "Premier Aqua" - Vrdnik, May 21 - 23, 2015, Scientific Veterinary Institute „Novi Sad“ and Institute of Veterinary Medicine of Serbia, ISBN 978-86-82871-36-1, 178-182.

43. Przybyłowski P., Wilczyńska A. 2001. Honey as an environmental marker. Food Chemistry, 74, 289-291.

44. Roman A., Madras-Majewska B., Popiela-Pleban E. 2011. Comparative study of selected toxic elements in propolis and honey. Journal of Apicultural Science, 55, 2, 97-106.

45. Roy, P., Saha, A. 2002. Metabolism and toxicity of arsenic: A human carcinogen. Current Science, 82, 1, 38-45.

46. Satarug S., Baker J.R., Urbenjapol S., Haswell-Elkins M., Reilly P.E., Williams D.J., Moore M.R. 2003. A Global Perspective on Cadmium Pollution and Toxicity in Non-Occupationally Exposed Population. Toxicology Letters, 137, 65-83. doi:10.1016/s0378-4274(02)00381-8.

47. Sadowska M., Gogolewska H., Pawelec N., Sentowska A., KrasnodębskaOstrega B. 2019. Comparison of the contents of selected elements and pesticides in honey bees with regard to their habitat. Environmental Science and Pollution Research, 26, 371-380. doi: 10.1007/s11356-018-3612-8.

48. Sergalio K.T.S., Silva B., Bergamo G., Brugnerotto P., Gonzaga L. V., Fett R., Costa A.C.O. 2019. An overview of physicochemical characteristics and health-promoting properties of honeydew honey. Food Research International, 119, 44-60. doi: 10.1016/j.foodres.2019.01.028.

49. Solayman M., Islam M.A., Paul S., Ali Y., Khalil M.I., Alam N., Gan S.H. 2016. Physicochemical Properties, Minerals, Trace Elements, and Heavy Metals in Honey of Different Origins: A Comprehensive Review. Comprehensive reviews in food science and food safety, 15, 219-233. doi: 10.1111/1541-4337.12182.

50. Sousa J.M.B., Soza L.E., Marques G., Benassi M.T., Gullon B., Pintado M.M. 2016. Sugar profile, physicochemical and sensory aspects of monofloral honeys produced by different stingless bee species in Brazilian semi-arid region. LWT - Food Science and Technology, 65, 645-651. doi: 10.1016/j.lwt.2015.08.058. 
51. Stoikou V., Andrianos V., Stasinos S., Kostakis M.G., Attiti S., Thomaidis N.S., Zabetakis I. 2017. Metal uptake by sunflower (Helianthus annuus) irrigated with water polluted with chromium and nickel. Foods, 6, 51. doi: 10.3390 / foods6070051.

52. Tutun H., Kahraman H.A., Aluc Y., Avci T., Ekici H. 2019. Investigation of some metals in honey samples from West Mediterranean region of Turkey. Veterinary Research Forum, 10(3), 181-186. doi: 10.30466/ vrf.2019.96726.2312.

53. Uršulin-Trstenjak N., Levanić D., Primorac Lj., Bošnir J., Vahčić N., Šarić G. 2015. Mineral profile of Croatian honey and differences due to its geographical origin. Czech Journal of Food Sciences, 33 (2), 156-164. doi: 10.17221/502/2014-CJFS.

54. Waldner C., Checkley S., Blakley B., Pollock C., Mitchell B. 2002. Managing lead exposure and toxicity in cow-calf herds to minimize the potential for food residues. Journal of Veterinary Diagnostic Investigation. 14(6), 481-6. doi: 10.1177/104063870201400606.

55. Živkov Baloš M., Jakšić S., Popov N., Mihaljev Ž., Ljubojević Pelić D. 2019. Comparative study of water content in honey produced in different years. Archives of Veterinary Medicine, 12, 1, 43-53. doi:10.46784/e-avm. v12i1.42.

56. Živkov Baloš M., Jakšić S., Popov N., Vidaković Knežević S., Ljubojević Pelić D., Pelić M., Polaček V., Milanov D. 2019a. Physicochemical characteristics of Serbian honeydew honey. Archives of Veterinary Medicine, 12, 2, 49-61. doi: 10.46784/e-avm.v12i2.62.

57. Živkov Baloš M., Mihaljev Ž., Popov N., Jakšić S., Ljubojević Pelić D., Pelić M., Polaček V. 2021. Toxic elements in Serbian sunflower honey originating from various regions. Biotechnology in Animal Husbandry, 37, 2, 149-160. doi: 10.2298/BAH2102149Z.

58. Živkov Baloš M., Popov N., Prodanov Radulović J., Stojanov I., Jakšić S. 2020. Sugar Profile of Different Floral Origin Honeys from Serbia. Journal of Apicultural Research, 59, 4, 398-405, doi: 10.1080/00218839.2020.1714193.

59. Živkov Baloš M., Popov N., Vidaković S., Ljubojević Pelić D., Pelić M., Mihaljev Ž., Jakšić S. 2018. Electrical conductivity and acidity of honey. Archives of Veterinary Medicine, 11, 1, 91-101. doi: 10.46784/e-avm.v11i1.20.

Received: 29.09.2021.

Accepted: 05.11.2021. 